\title{
Microbiological profile in Serra ewes' cheese during ripening
}

\author{
A.C. Macedo, F.X. Malcata and T.A. Hogg \\ Escola Superior de Biotecnologia, Universidade Católica Portuguesa, Porto, Portugal
}

\begin{abstract}
A.C. MACEDO, F.X. MALCATA AND T.A. HOGg. 1995. The microflora of Serra cheese was monitored during a $35 \mathrm{~d}$ ripening period at three different periods within the ewe's lactation season. After $7 \mathrm{~d}$ ripening, the numbers of micro-organisms reached their maximum, and lactic acid bacteria (LAB) and coliforms were the predominant groups. Pseudomonads were not detected after 1 week of ripening. At all stages of ripening, cheeses manufactured in spring exhibited the lowest numbers of LAB and yeasts, whereas cheeses manufactured in winter showed the lowest numbers of coliforms and staphylococci.

Leuconostoc lactis was the most abundant LAB found in Serra cheese whereas Enterococcus faecium and Lactococcus lactis spp. lactis exhibited the highest decrease in percentage composition. Numbers of both Leuc. mesenteroides and Lactobacillus paracasei tended to increase throughout ripening. The most abundant coliform was Hafnia alvei. Klebsiella oxytoca was found in curd but declined in number during ripening. Staphylococcal flora of curd was mainly composed of Staphylococcus xylosus, Staph. aureus and Staph. epidermidis. Staphylococcus xylosus was the major species found at the end of ripening. Pseudomonas fluorescens was the only Pseudomonas species isolated from the curd. Although a broad spectrum of yeasts were found in Serra cheese, Sporobolomyces roseus was the most abundant yeast isolated.
\end{abstract}

\section{INTRODUCTION}

Serra da Estrela cheese (or simply Serra cheese) is a semisoft cheese variety manufactured at the farm level from raw ewes' milk using traditional methods in the mountainous centre region of Portugal. This cheese is made in batches twice daily (early morning and late afternoon) from October to May using the unpasteurized milk immediately after collection. Coagulation is catalysed by a crude vegetable rennet, which consists of a suspension of the dry flowers of Cynara cardunculus, prepared at room temperature and filtered through a piece of cotton cloth. Coagulation takes place at $27-30^{\circ} \mathrm{C}$ for $1-2 \mathrm{~h}$. Once the right degree of consistency is attained, the curd is cut in irregularly shaped pieces, mainly by hand. After cutting, the curd is poured into perforated plastic moulds and lightly pressed by hand, and the cheese is salted by rubbing dry salt on the surface. Cheeses are ripened on wood shelves, namely in a basement for $c a 40 \mathrm{~d}$. The use of Bordaleira ewes' milk which possesses a high fat content (6-20\%) (Macedo et al. 1993), coupled with the use of the vegetable rennet, which possesses a strong, unselective proteolytic activity (Barbosa et

Correspondence to: Dr F. Xavier Malcata, Escola Superior de Biotecnologia, Universidade Católica Portuguesa, Rua Dr António Bernardino de Almeida, 4200 Porto, Portugal. al. 1981), results in a cheese with unique bouquet and creamy texture.

Studies on the microbial flora of ripened Serra cheese have been reported by Hiscox et al. (1941), Cruz (1945) and Antunes and Santos (1943); however, very little was known until recently about the nature and the evolution of the main microbial groups during ripening. Studies focused on the changes in the numbers of the main groups of microorganisms in the interior and on the surface of Serra cheese, throughout the lactation season, and during ripening have been conducted by Macedo et al. (1995). The aim of the present study was to complement such previous information via the identification of the species of lactic acid bacteria (LAB), yeasts, coliforms, staphylococci and pseudomonads in Serra cheese during ripening and throughout the lactation season; such work was developed hoping that a standardized starter suitable for Serra cheese manufacture will eventually be possible.

\section{MATERIALS AND METHODS}

\section{Manufacture and sampling of cheese}

Three batches of $120.5 \mathrm{~kg}$ Serra cheeses were manufactured and ripened according to the traditional practice 
(Macedo et al. 1993) in November, February and May in an attempt to adequately represent autumn, winter and spring manufactures. The 12 cheeses were randomly divided into four sets of three cheeses each; one set picked at random was sent to this laboratory on the day of cheesemaking, and the others after $7 \mathrm{~d}, 21 \mathrm{~d}$ and $35 \mathrm{~d}$ of ripening, respectively. All samples were transported under refrigerated conditions $\left(\mathrm{ca} 4^{\circ} \mathrm{C}\right.$ ). Sampling of the interior of the cheese and all microbiological analyses thereafter were performed immediately upon receipt of the cheeses $(<1 \mathrm{~h})$.

\section{Microbiological analyses}

Ten $\mathrm{g}$ of each cheese sample were homogenized with $90 \mathrm{ml}$ of a sterile solution of $2 \%(w / v)$ sodium citrate (Merck, Darmstadt, Germany) at $45^{\circ} \mathrm{C}$ for $1 \mathrm{~min}$ in a Stomacher Lab-Blender 400 (Seward Medical, London, UK). Decimal dilutions were prepared in sterile $0.1 \%$ peptone water (Sigma Chemical, St Louis, MO, USA) and plated in duplicate. Lactic acid bacteria (LAB) were grown anaerobically (Gas-Pak anaerobic system BBL, Cockeysville, MD, USA) on M17 Agar (M17A; LabM, Bury, UK) and on Rogosa Agar (RA; Oxoid, Basingstoke, UK) at $30^{\circ} \mathrm{C}$ for 3 and $5 \mathrm{~d}$. Cycloheximide (Sigma) was added $\left(100 \mathrm{mg} \mathrm{l}^{-1}\right)$ to prevent the growth of yeasts (Kandler and Weiss 1986). Coliforms were determined on Violet Red Bile Agar (VRBA; Lab M) and staphylococci on Baird-Parker egg yolk tellurite medium (BPM; Lab $\mathrm{M}$ ), at $37^{\circ} \mathrm{C}$ for 1 and 2 d, respectively. Pseudomonads were grown on Pseudomonas Base Agar (PSDA; LabM) supplemented with cephaloridine, fucidin and cetrimide (Lab $M$ ) and yeasts on Potato Dextrose Agar (PDA; LabM) acidified with 10\% lactic acid (Merck), at $25^{\circ} \mathrm{C}$ for $2 \mathrm{~d}$ and $5 \mathrm{~d}$, respectively. The technique of surface viable count was used for all media except VRBA for which the pour-plate and overlay technique was used. Results were expressed as $\mathrm{cfu}^{-1}$ of cheese.

For the curd and 35-d-old cheese, as well as from each of the aforementioned agars, colonies with different morphologies were counted, picked (three colonies of each type), purified, and stored at $4^{\circ} \mathrm{C}$ as slope cultures until further characterization.

\section{Identification of micro-organisms}

The API $50 \mathrm{CHL}$ system (BioMérieux, Marcy-l'Etoile, France) was used to identify to the species level the following genera: (i) Lactobacillus (Gram-positive, catalasenegative rods); (ii) Leuconostoc (Gram-positive, catalase-negative, non-producers of ammonia from arginine and heterofermentative cocci); (iii) Lactococcus (Grampositive, catalase-negative and homofermentative cocci that grow at $10^{\circ}$ but not at $45^{\circ} \mathrm{C}$ ). Identification of enterococci (considered here as Gram-positive, catalase-negative, homofermentative cocci that grow at both $10^{\circ}$ and $45^{\circ} \mathrm{C}$ ) was performed using the API STREP system (BioMérieux). Coliforms (considered here as Gramnegative, catalase-positive, glucose-fermenters, nitratepositive and oxidase-negative short rods) were identified by the API 20E system (BioMérieux). Staphylococci (considered here as Gram-positive, glucose-fermenters under anaerobic conditions and catalase-positive cocci) were identified by the API STAPH system (BioMérieux). Staphylococcus aureus were confirmed by testing coagulation of lyophilized rabbit plasma (BioMérieux) at $37^{\circ} \mathrm{C}$ within $24 \mathrm{~h}$. Results obtained from the different API systems were matched with the aid of a commercially available software for the automatic identification of bacteria (Anon. 1993). Identification of pseudomonads (considered here as Gram-negative and oxidase-positive rods) was according to the method of Collins and Lyne (1984). Biochemical and physiological characterization of yeasts included: (i) assimilation of carbon compounds such as Larabinose, cellobiose, erythritol, galactose, gluconate, glucosamine, glucose, $\alpha$-methyl-D-glucoside, glucuronate, glycerol, 2-keto-gluconate, DL-lactate, lactose, mannitol, maltose, melibiose, melezitose, raffinose, rhamnose, ribose, saccharose, sorbose, trehalose and D-xylose; (ii) assimilation of nitrogen compounds (nitrate); and (iii) temperature tolerance (growth at $25^{\circ}, 30^{\circ}$ and $37^{\circ} \mathrm{C}$ ). In addition, morphological criteria such as budding/splitting of cells and colony pigmentation were taken into account. The computer program of Barnett et al. (1990) was used for automatic identification of yeasts.

\section{Statistical analysis}

ANOVA tables (not shown) were constructed with the replicated data pertaining to the numbers of micro-organisms vs the factors ripening time and period within the lactation season.

\section{RESULTS}

The data statistically significant on the $5 \%$ level encompassing the numbers of $\mathrm{LAB}$ on M17A, LAB on RA, coliforms on VRBA, staphylococci on BPM, and yeasts on PDA are plotted in Figs 1, 3, 5, 7 and 9, respectively, as the average of the three replicates considered in ANOVA tables. The percentage composition in terms of microbial species of each of the aforementioned groups for both the curd and the 35-d-old cheese are depicted in Figs 2, 4, 6, 8 and 10.

\section{DISCUSSION}

Inspection of Figs 1, 3, 5, 7 and 9 indicates that the growth patterns of the main groups of micro-organisms studied, as 
Fig. 1 Changes in numbers of lactic acid bacteria of Serra cheese (grown on Ml7 agar) with ripening time and period in ewes' lactation season. $\square$, Spring; 娄, winter; $\square$, autumn

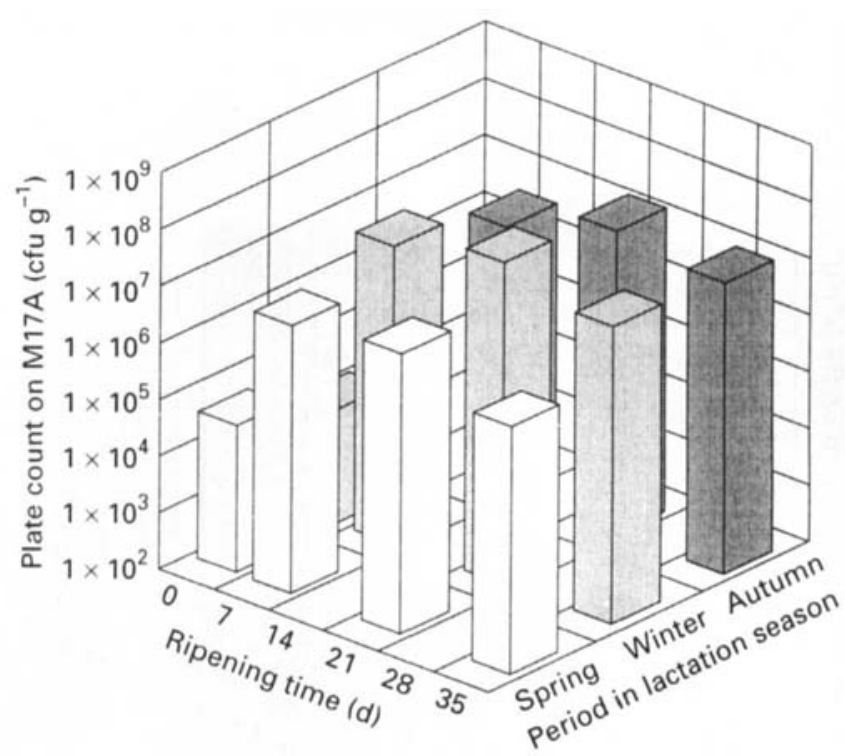

(a2)

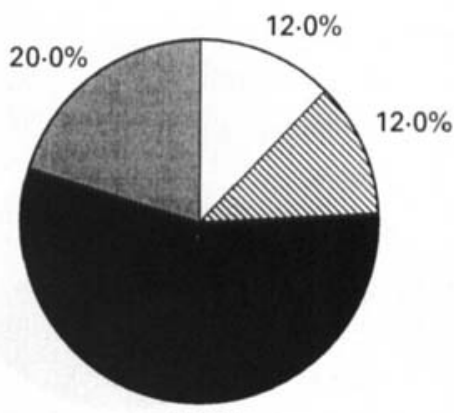

$56.0 \%$

(b2)

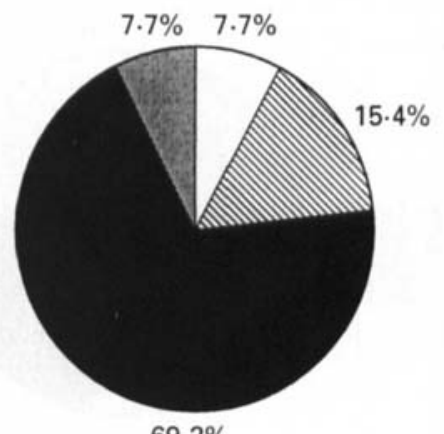

$69.2 \%$

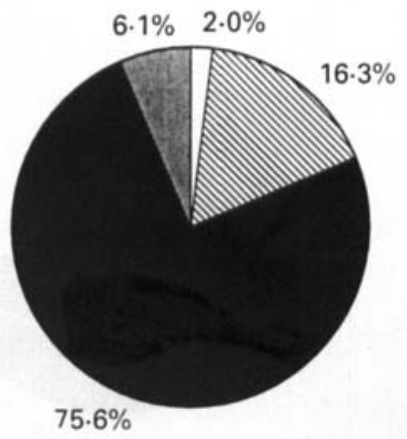

Fig. 2 Composition of LAB of Serra cheese (grown on M17A) in (1) curd and (2) 35-d-old cheese, produced in (a) autumn, (b) winter, and (c) spring, in terms of Enterococcus faecium ( $\square$ ), Lactococcus lactis ssp. lactis $(\mathbb{Q})$, Leuconostoc lactis ( $\mathbf{\square})$, Leuc. mesenteroides ssp. mesenteroides/dextranicum (잠) (c2) (c1)

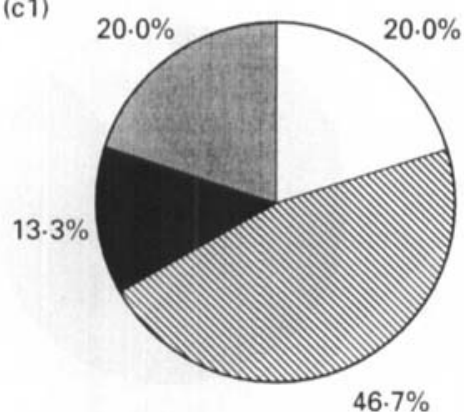

$46.7 \%$

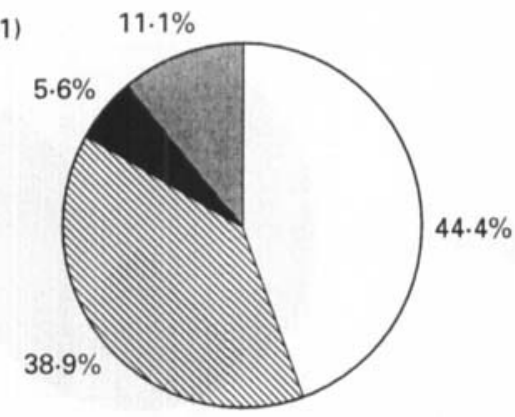




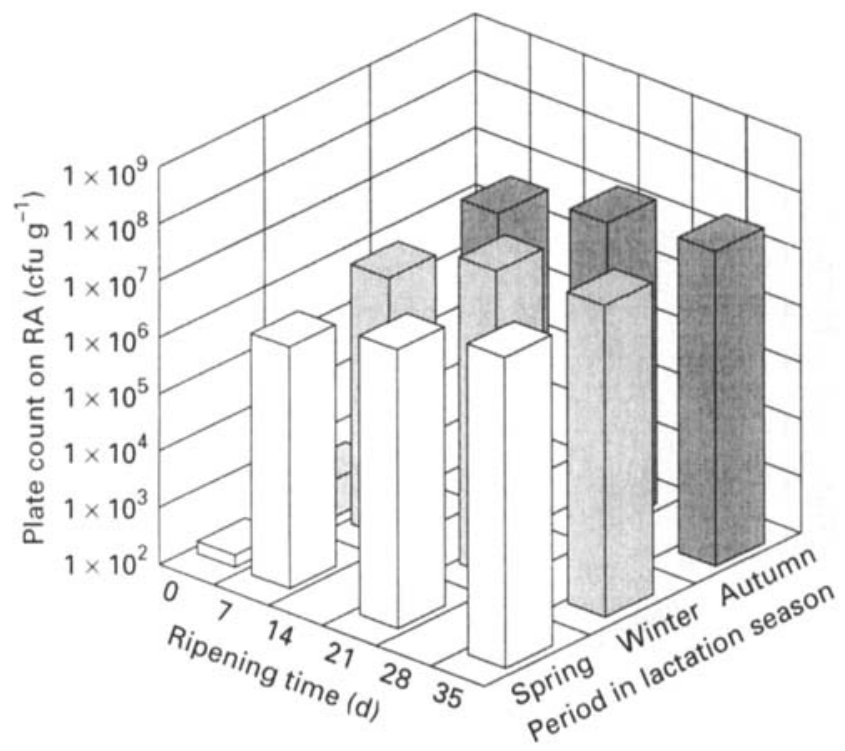

Fig. 3 Changes in numbers of LAB of Serra cheese (grown on Rogosa agar) with ripening time and period in ewes' lactation season. $\square$, Spring; 圈, winter; $\square$, autumn (a1)

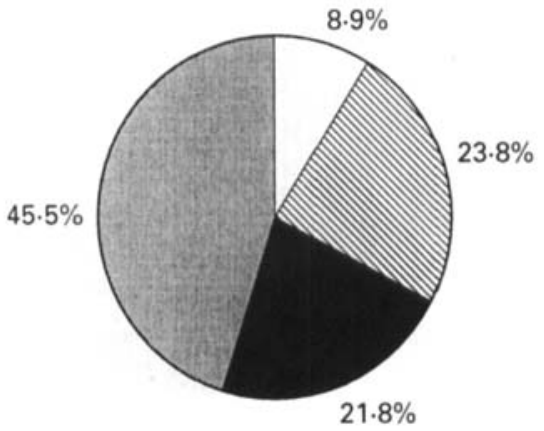

(b1)

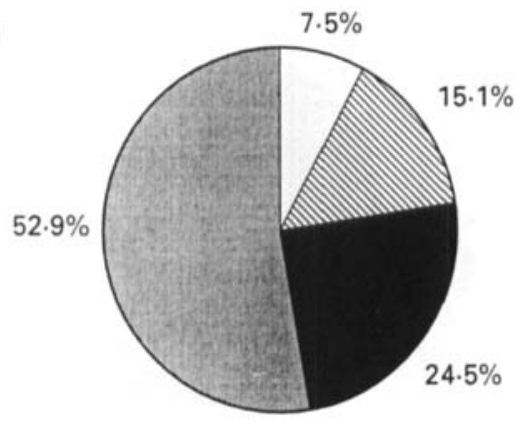

(c1)

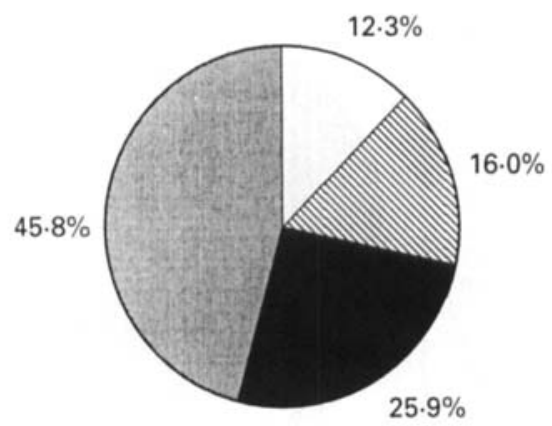

(a2)

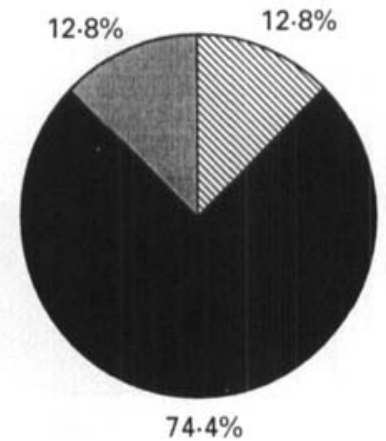

(b2)

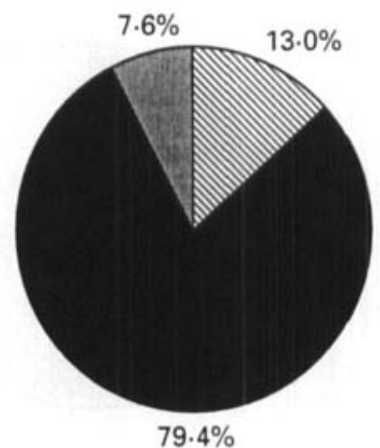

(c2)

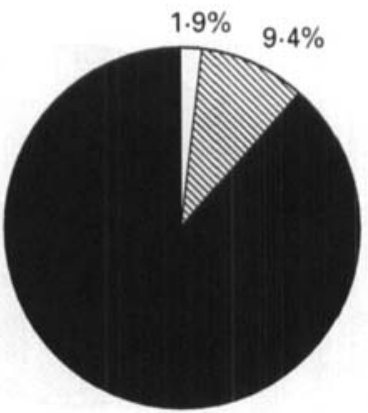

$88.7 \%$
Fig. 4 Composition of LAB of Serra cheese (grown on RA) in (1) curd and (2) 35 -d-old cheese, produced in (a) autumn, (b) winter, and (c) spring, in terms of Lactobacillus plantarum ( $\square$ ), Lact. paracasei ssp. paracasei (\$), Leuconostoc lactis ( $\square$ ) and Leuc. mesenteroides ssp. mesenteroides/dextranicum (圆) 
Fig. 5 Changes in numbers of coliforms of Serra cheese (grown on Violet Red Bile Agar) with ripening time and period in ewes'

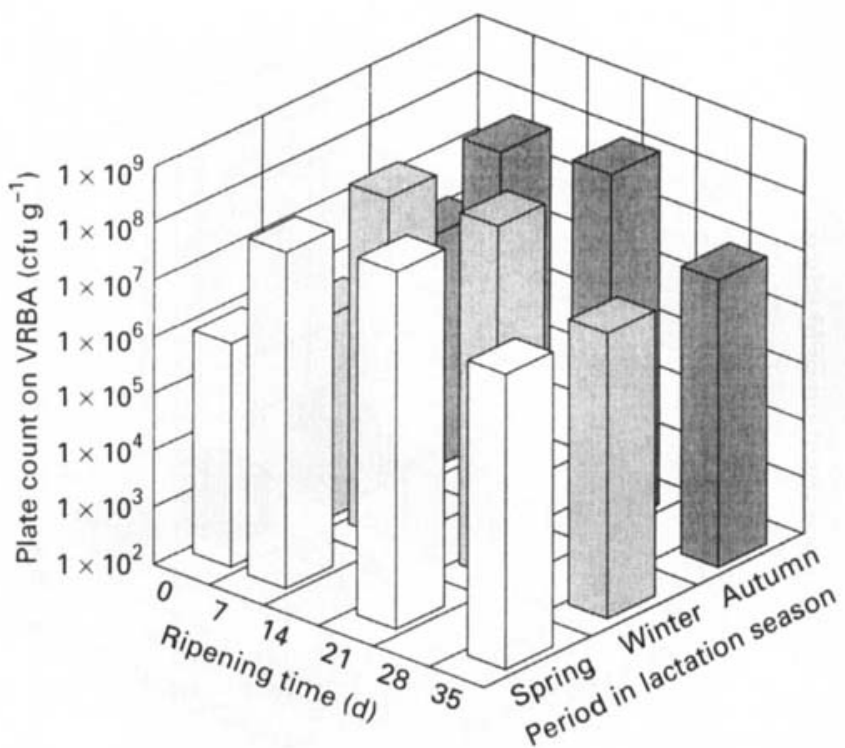
lactation season. $\square$, Spring; …… winter; $\square$, autumn

(a1)

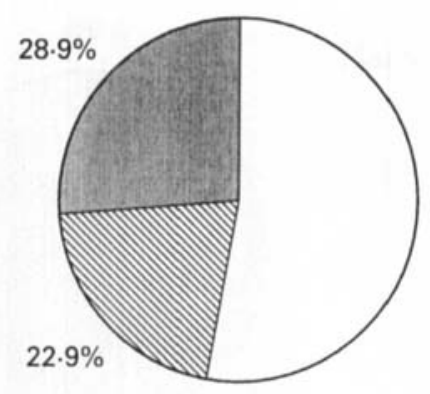

(b1)

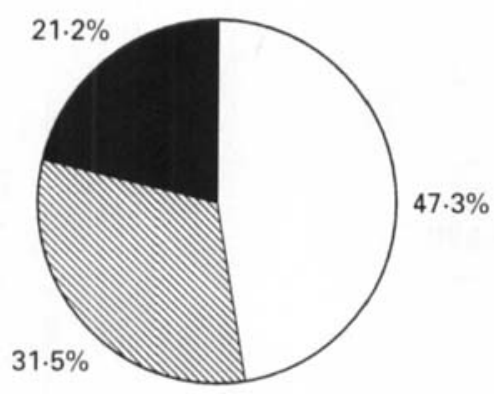

(c1)

FIg. 6 Composition of coliforms of Serra cheese (grown on VRBA) in (1) curd and (2) 35-d-old cheese, produced in (a) autumn, (b) winter, and (c) spring, in terms of Hafnia alvei ( $\square$ ), Klebsiella oxytoca $(\mathbb{Q})$, Escherichia coli $(\square)$ and Citrobacter freundii (䍕) (a2)

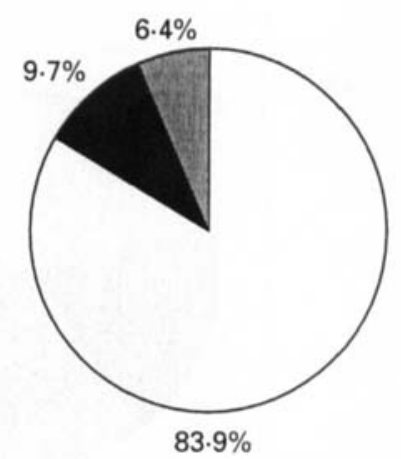

(b2)

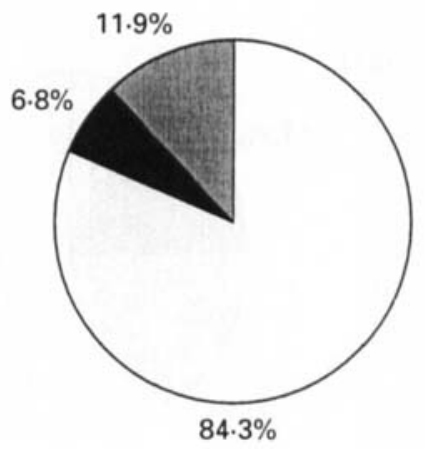

(c2)

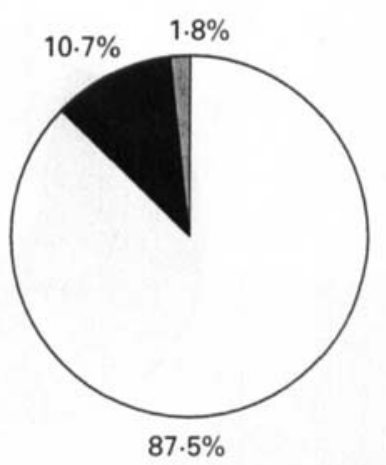




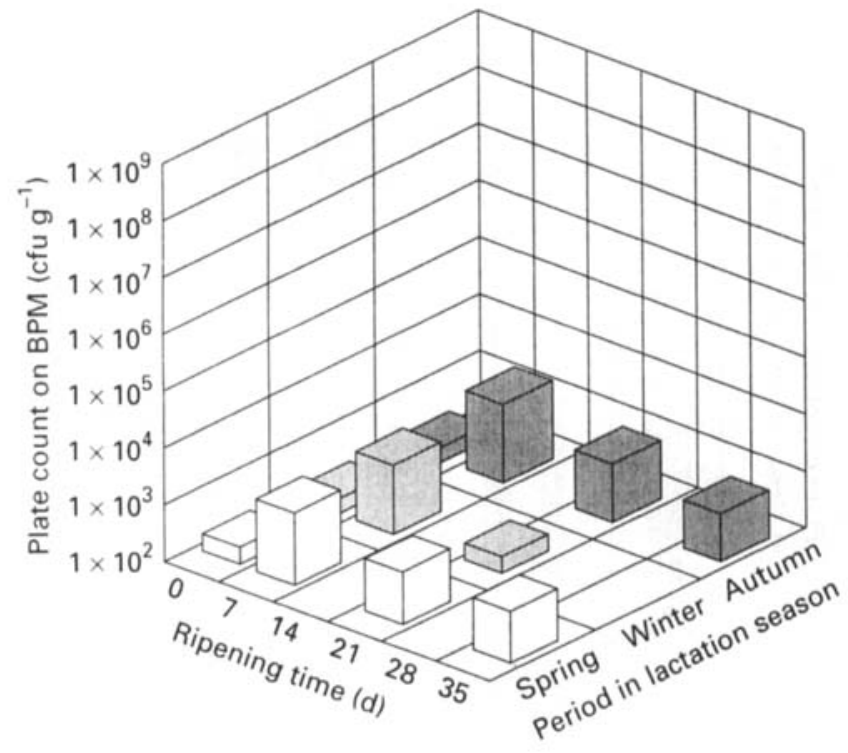

Fig. 7 Changes in numbers of staphylococci of Serra cheese (grown on Baird-Parker Medium) with ripening time and period in ewes' lactation season. $\square$, Spring; 疄, winter; $\square$, autumn (a1)

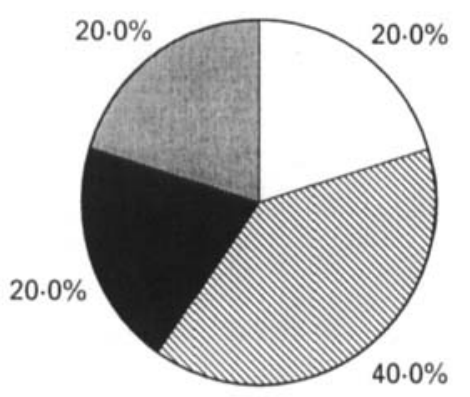

(b1)

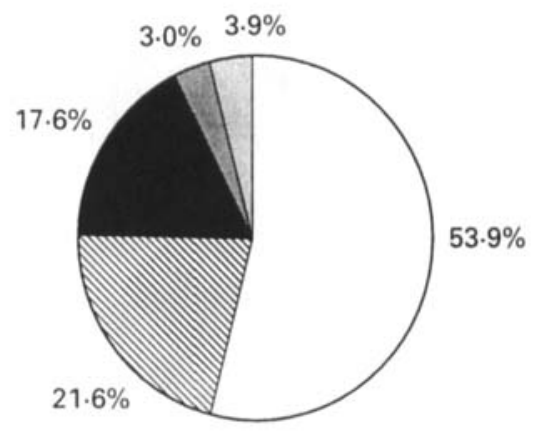

(c1)

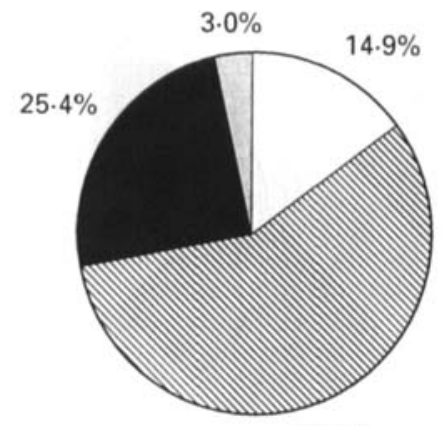

$56.7 \%$ (a2)

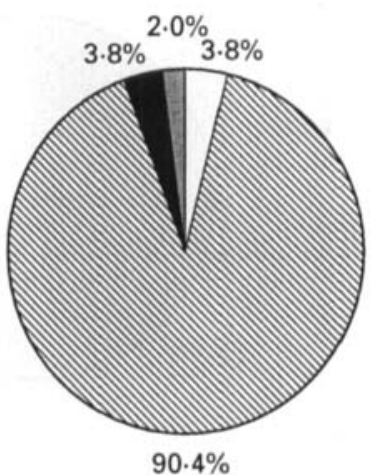

$90.4 \%$

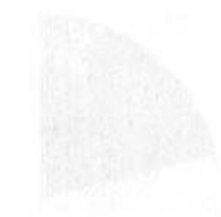

.

(c2)

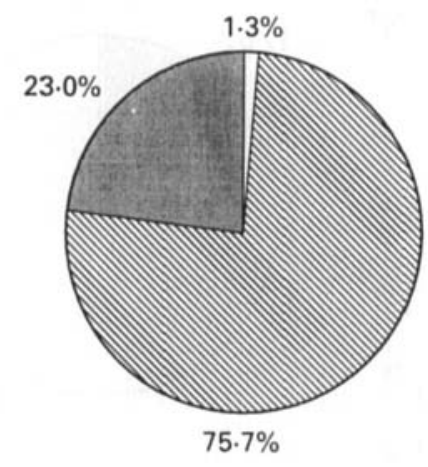

Fig. 8 Composition of staphylococci of Serra cheese (grown on BPM) in (1) curd and (2) 35-d-old cheese, produced in (a) autumn, (b) winter, and (c) spring, in terms of Staphylococcus aureus ( $\square)$, Staph. xylosus (\$), Staph. epidermidis ( $\square$ ), Staph. simulans (1) and Staph. hominis (阅) 
Fig. 9 Changes in numbers of yeasts of Serra cheese (grown on Potato Dextrose Agar) with ripening time and period in ewes'

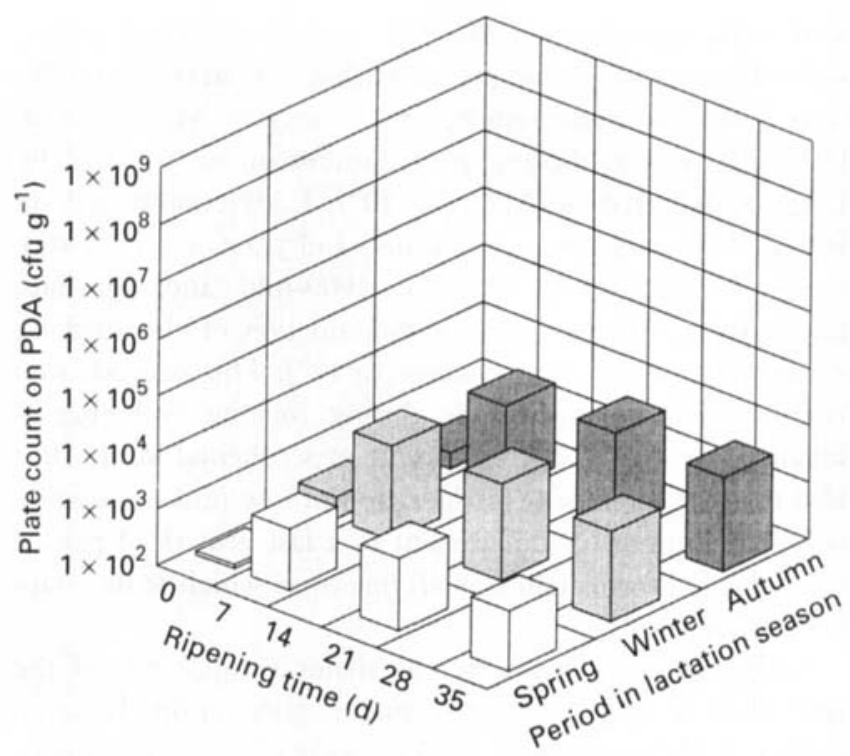
lactation season. $\square$, Spring;

(a1)

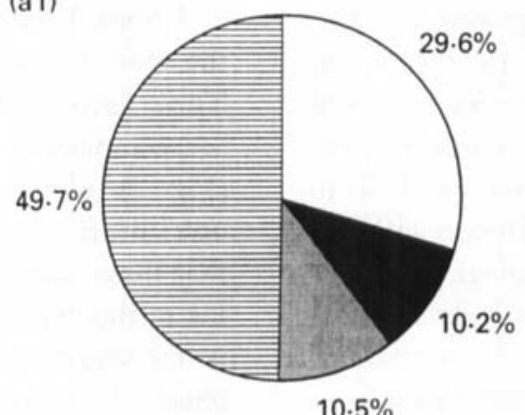

(b1)

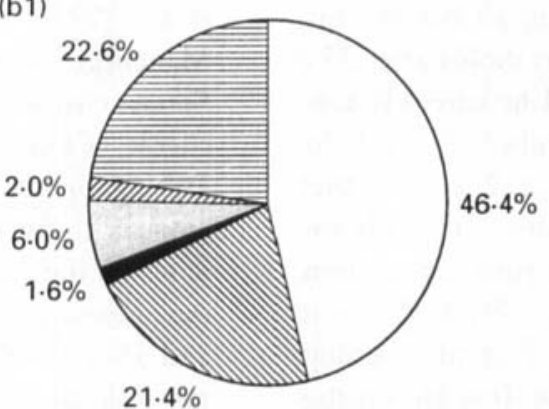

(c1)

Fig. 10 Composition of yeasts of Serra cheese (grown on PDA) in (1) curd and (2) 35-d-old cheese, produced in (a) autumn, (b) winter, and (c) spring, in terms of Sporobolomyces roseus ( $\square$ ), Kluyveromyces marxianus (\$), Rhodotorula aurantiaca

(), Yarromia lipolytica (国), Pichia membranaefaciens (잉), Trichosporum beigelii (四), Leucosporidium scottii/Debaryomyces hansenii (目)
$10.5 \%$

(a2)

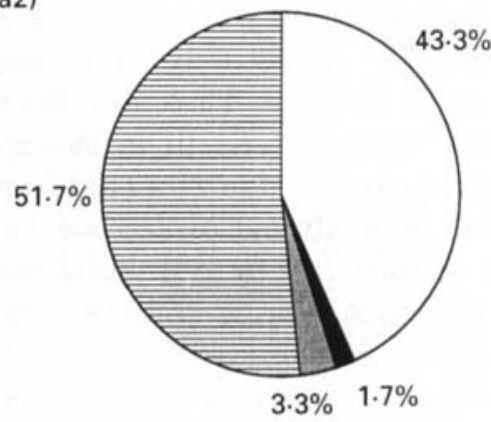

(b2)

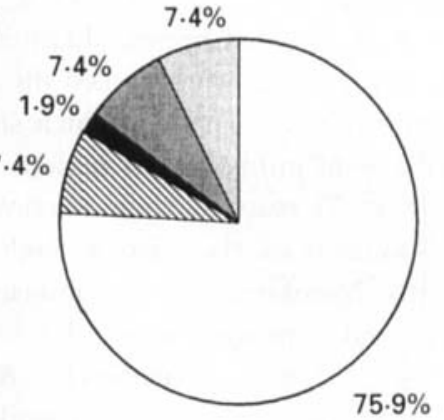

(c2) $52 \cdot 8 \%$
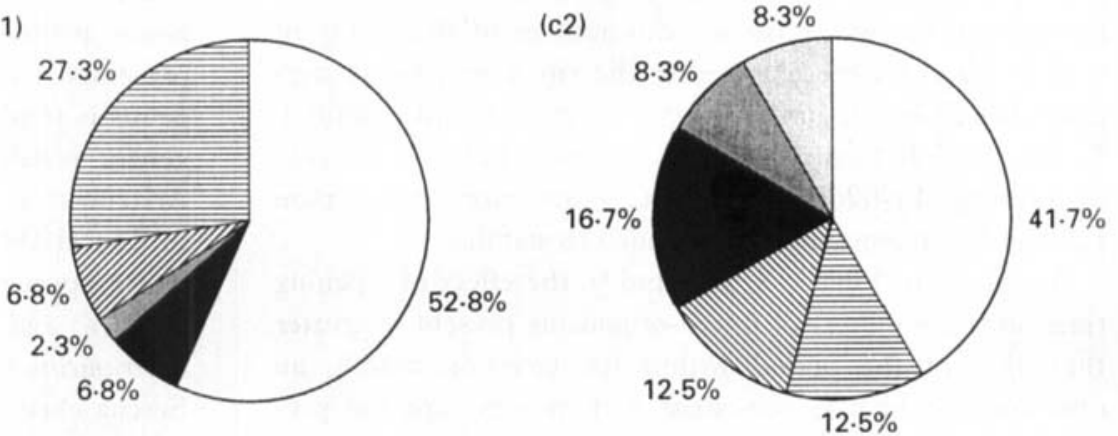
well as the growth rates of LAB, staphylococci and yeasts, with ripening time and period within the lactation season were similar to those reported previously by Macedo et al. (1995). However, the initial contamination of the curd by LAB enumerated on M17 ( $\left.c a 10^{4}\right)$, LAB enumerated on RA $\left(c a 10^{2}\right)$, staphylococci $\left(c a 10^{2}\right)$ and yeasts $\left(c a 10^{2}\right)$ were lower by 1000-fold, 100-fold, 1000-fold and 100-fold, respectively, whereas initial contamination of the curd by coliforms tended to be the same $\left(c a 10^{6}\right)$. This suggests that better standards of hygiene during milking and cheesemaking were used in the present experimental study, but also that the inefficient refrigeration of raw milk is possibly still contributing to some extent to a fast growth of psychrotrophic coliforms (such as Hafnia alvei which is the main coliform in curd).

$\mathrm{LAB}$ and coliforms were the major components of the microflora during ripening throughout the entire lactation season. LAB enumerated on M17 agar (Fig. 1), LAB enumerated on RA (Fig. 3) and coliforms (Fig. 5) increased their numbers during the first week of ripening by $10^{3}$, $10^{4}$ and $10^{2}$, respectively, with respect to the initial numbers in the curd. Thereafter, the tendencies exhibited by these bacteria were: (i) to increase at a much lower growth rate from $7 \mathrm{~d}$ to $21 \mathrm{~d}$ (10-fold increase); and (ii) to stabilize for LAB and to decrease for coliforms (10-fold decrease) from $21 \mathrm{~d}$ to $35 \mathrm{~d}$. Strict microbiological regulations concerning cheese made from raw milk do not formally exist in Portugal; however, Spanish regulations pertaining to some cheese varieties manufactured from pasteurized milk specify maximum counts of $10^{4} \mathrm{cfu}^{-1}$ for Enterobacteriaceae and $10^{3} \mathrm{cfu}^{-1}$ for Escherichia coli (Gaya et al. 1983). Cheeses obtained from all batches utilized in the present work exceed those thresholds after $35 \mathrm{~d}$ of ripening (Fig. 5), figures which should be carefully considered due to public health reasons. Numbers of staphylococci (Fig. 7) reached their maximum at $7 \mathrm{~d}$, and they tended to decrease thereafter at higher rates than LAB and coliforms. Numbers of pseudomonads in curd for autumn, winter and spring, were $1.2 \times 10^{3}, 2.6 \times 10^{3}$ and $2.3 \times 10^{3} \mathrm{cfu} \mathrm{g}^{-1}$, respectively. After $7 \mathrm{~d}$ of ripening, numbers of pseudomonads were negligible. It is known that certain pseudomonads exhibit proteolytic and lipolytic extracellular activities that may cause undesirable effects in texture and flavour; however, the number of this group of micro-organisms present during the ripening process suggests that their role in flavour development is quite limited. Yeasts (Fig. 9) tended to increase during the first 2 weeks of ripening (10-fold increase), but much more slowly than $\mathrm{I} . \mathrm{AB}$ and coliforms, and then tended to stabilize.

As shown in Figs 1, 3, 5, 7 and 9, the effect of ripening time on the numbers of micro-organisms present is greater than that of the period within the lactation season, an observation which is consistent with results reported pre- viously by Macedo et al. (1995). LAB and yeasts were favoured by the environmental conditions prevailing in the maturation rooms during winter and autumn, i.e. lower temperatures and higher relative humidities than in spring; conversely, staphylococci and coliforms survived better in spring. Fernandez del Pozo et al. (1988) reported that lower counts of coliforms were obtained in La Serena cheese made in spring than in winter. Following the consideration of the inhibitory effect of LAB on the growth of coliforms in Manchego cheese (Gaya et al. 1983), the higher numbers of $\mathrm{LAB}$ recorded in winter might explain the apparent accelerated decrease of coliforms during this period. The initial contaminations by coliforms and staphylococci in Serra cheese are also in agreement with seasonal variations of coliform counts in raw ewes' milk which apparently decrease from autumn to spring (Gaya et al. 1987), and with seasonal variations of staphylococci counts in raw ewes' milk which have been reported as highest in spring and lowest in winter (Bautista et al. 1986).

Among LAB, L. lactis ssp. lactis and Ent. faecium were the most abundant bacteria found in curd (Figs 2 and 4). These bacteria showed the largest decrease in their percentage composition from the curd to the fully ripened cheese (Fig. 2). However, the presence of lactococci and enterococci during the late stages of maturation (Fig. 2) suggests that these bacteria may play an important role in the ripening of this type of cheese. It has been reported that $L$. lactis is the most abundant Lactococcus species in La Serena cheese (Fernandez del Pozo et al. 1988), Hrudkovy and Bryndza cheeses (Prekoppova 1990), and L. lactis ssp. lactis is the most abundant subspecies in Roncal cheese (Arizcun et al. 1992). Enterococcus faecium is commonly found in Manchego cheese (Nuñez and Martínez-Moreno 1976), La Serena cheese (Fernandez del Pozo et al. 1988) and Teleme cheese (Tzanetakis and Liptopoulou-Tzanetaki 1992). During ripening, however, the bacterium that grows faster appears to be Leuc. lactis (Figs 2 and 4) because it dominates in the fully ripened cheese. Leuconostoc mesenteroides ssp. mesenteroides/dextranicum was also found in both curd and 35-d-old cheese. Leuconostoc species can play an important role in aroma development and eye formation through their ability to metabolize citrate and ferment carbohydrates, respectively. The predominance of the Leuconostoc genus in Serra cheese is consistent with results presented elsewhere: Nuñez et al. (1984) reported that this genus is predominant in the Gram-positive psychrotrophic genera obtained from refrigerated raw ewes' milk, and Arizcun et al. (1992) reported high numbers of Leuconostoc in Roncal cheese. (In this latter case, ca $20 \%$ of the Leuconostoc species found were Leuc. mesenteroides ssp. mesenteroides and ca $24 \%$ were Leuc. mesenteroides ssp. dextranicum.) The main Leuconostoc species found in La Serena cheese was Leuc. mesenteroides (Fernandez del Pozo 
et al. 1988). Leuconostoc species have been also deliberately added to Manchego cheese as a part of the microbial starter with good results (Ramos et al. 1990). Among the genus Lactobacillus, Lact. plantarum and Lact. paracasei ssp. paracasei could be identified in the curd (Fig. 4). During ripening, Lact. paracasei ssp. paracasei tended to grow while Lact. plantarum tended to disappear, indicating a possible role for Lact. paracasei ssp. paracasei in Serra cheese maturation. It has been asserted that Lact. plantarum and Lact. casei were the dominant lactobacilli in La Serena cheese (Fernandez del Pozo et al. 1988), Hrudkovy and Bryndza cheeses (Prekoppova 1990), and Roncal cheese (Arizcun et al. 1992), and that Lact. plantarum was the predominant lactobacillus in Feta and Teleme cheeses (Tzanetakis and Liptopoulou-Tzanetaki 1992). The data presented in the present study also indicate that lactation season has an influence on the initial contamination of the curd and the growth of each group of LAB throughout ripening. The level of enterococci has been correlated with the level of hygiene during milk processing (Thompson and Marth 1986); higher values of the percentage composition of Ent. faecium in the curd (Fig. 2) in winter than in autumn or spring might be explained by the poor housing conditions in winter, when the animals spend most of their time in stables due to adverse weather. The ripening conditions in spring contributed preferentially to the growth of Leuc. lactis (Figs 2 and 4) with respect to such other lactic cocci as Leuc. mesenteroides ssp. mesenteroides/dextranicum and Ent. faecium. The lowest percentage compositions of $L$. lactis ssp. lactis (Fig. 2) and Lact. paracasei ssp. paracasei (Fig. 4) were obtained in autumn and spring, respectively.

As a result of the absence of good sanitary conditions during milking and cheesemaking, coliforms are, like enterococci, important elements of the bacterial inventory of raw ewes' milk. The levels of coliforms found in the present work (which are of the same order of magnitude as those of LAB) are of considerable public health concern and technological relevance for Serra cheese since this cheese variety is made directly from raw ewes' milk without any type of thermal processing. Hafnia alvei was the most abundant and proliferating coliform found both in the curd and the 35-d-old cheese (Fig. 6). Gaya et al. (1983) also isolated $H$. alvei in very high proportions in 60-d-old Manchego cheese, and Kleeberger et al. (1980) stated that $H$. alvei is the typical coliform isolated from milk and dairy products. Nuñez et al. (1984) concluded that refrigeration of raw ewes' milk had effects of decreasing or increasing the counts of psychrotrophs depending on whether the refrigeration was made at $4^{\circ}$ or $7^{\circ} \mathrm{C}$, respectively. Additionally, Juven et al. (1981) reported that psychrotrophic Enterobacteriaceae exhibited proteolytic and lipolytic activities during refrigeration. Considering that the raw ewes' milk used for Serra cheesemaking is lightly refrigerated below room tem- perature, one concludes that the predominance of $H$. alvei (as a psychrotrophic bacterium) may play an important role in ripening of Serra cheese. Gaya et al. (1987) reported that $H$. alvei and Klebsiella oxytoca were the predominant species in dairy farm samples. Klebsiella oxytoca was found in the curd but not in the 35-d-old cheese (Fig. 6). This fact may be partly accounted for by the weak resistance of this species to low $\mathrm{pH}$; Tornadijo et al. (1993) also found $K l$. oxytoca in the curd but not in 1- or 2-week-old cheeses made from raw goats' milk which undergo $\mathrm{pH}$ variations similar to those in Serra cheese (Macedo et al. 1995). Escherichia coli was isolated from all ripened cheeses but only from the curd during the winter period; since it is able to ferment lactose, it may be responsible for the development of pin eyeholes in cheese. Failure to isolate $E$. coli until virtual completion of ripening may be probably attributed to the fact that the initial contamination of milk by these bacteria is very low when compared with contamination by other micro-organisms. Since $E$. coli is particularly resistant to such adverse conditions as the low $\mathrm{pH}$ which tends to develop towards the end of the ripening period, this bacterium is likely to increase its percentage composition importance as time elapses. Gaya et al. (1983) reported that Enterobacter aerogenes, $E$. coli and $H$. alvei were the most resistant species against the acidic environment generated by lactic acid bacteria. Citrobacter freundii was found in both curd and 35-d-old cheese, and its percentage composition was lowest in spring and highest in winter (Fig. 6).

Due to their low numbers during ripening ( $c a 1^{2}$ ), staphylococci are not likely to play as important a role in the maturation process as LAB (Fig. 7). The predominant Staphylococcus species found in curd were Staph. xylosus, Staph. aureus and Staph. epidermidis, and at lower proportions, Staph. simulans and Staph. hominis (Fig. 8). Similar staphylococci species have been reported by Bautista $e t$ al. (1986) and Nuñez et al. (1989) for ewes' milk, and by Fernandez del Pozo et al. (1988) for ewes' cheese. Staphylococcus aureus showed a tendency to disappear as ripening time elapses (Fig. 8), so it is less likely that it causes health hazards by the normal time of cheese consumption (i.e. 45 d). For ewes' milk, Bautista et al. (1986) reported higher values for the percentage composition of coagulase-positive staphylococci in spring than in the rest of the year; coagulase-positive staphylococci were not detected in La Serena cheese after $45 \mathrm{~d}$ (Fernandez del Pozo et al. 1988). The highest percentage composition of coagulase-positive strains among the staphylococci in curd was observed in winter. However, these species were less resistant in this period than in either spring or autumn since they could not be found in the 35-d-old cheese. This observation probably can be explained by the fact that more acidic cheese matrices, which are unfavourable to the growth of 
coagulase-positive strains, are observed in winter (Macedo et al. 1995). Staphylococcus xylosus is the most abundant of the staphylococci in curd in the autumn and spring, whereas Staph. aureus is the most abundant species in winter; Staph. xylosus is also the most resistant and fastest growing bacteria during ripening (Fig. 8). Staphylococcus epidermidis was found in the curd and tended to disappear as ripening progressed; the percentual compositions associated with this strain in the curd and in the three periods within the lactation season were similar (Fig. 8). Initial contamination of the curd by Staph. simulans was highest in the autumn and lowest in the spring. However, this bacterium proved to be more resistant in spring than in autumn (Fig. 8). This fact probably can be correlated with the higher $\mathrm{pH}$ in cheese and higher ripening temperatures observed in spring (Macedo et al. 1995). Staphylococcus hominis was found in the curd at very low proportions and could not be detected in the 35-d-old cheese.

Among the Pseudomonas species, Ps. Auorescens was the only one found in Serra cheese. Nuñez et al. (1984) have stated that Pseudomonas are the predominant psychrotrophic genus in refrigerated raw ewes' milk, although $H$. alvei was also found. For Serra cheese, $H$. alvei is more abundant than Ps. fluorescens.

Although the numbers of yeasts are $10^{4}$-fold lower than those of $\mathrm{LAB}$, they deserve special attention because some yeasts are able to synthesize lipolytic and proteolytic enzymes which may eventually contribute to the development of aroma and flavour during ripening. It is, however, well established that their major contribution to the ripening process is the utilization of lactic acid, which, by increasing the $\mathrm{pH}$, encourages growth of the bacteria sensitive to acidic environments, and thus helps initiating the second stage of maturation. Since yeasts are ubiquitous in agricultural environments, a broad spectrum of yeasts was, as expected, found in the cheese samples analysed (Fig. 10). Sporobolomyces roseus and Leucosporidium scottiil Debaryomyces hansenii (lactose-utilizing yeasts) were the predominant yeasts in both the curd and the 35-d-old cheese, but their proportions were dependent on lactation season (Fig. 10); the highest proportions occurred in the spring and the autumn, respectively. Predominance of lactic acid-utilizing yeasts over lactose-utilizing yeasts in $\mathrm{La}$ Serena cheese were reported by Fernandez del Pozo et al. (1988). Sporobolomyces roseus was, on the other hand, more resistant and more actively growing in winter than in autumn and spring. This observation is in agreement with previous data (Macedo et al. 1995) indicating that the lowest $\mathrm{pH}$ values in cheese occur in winter; therefore, higher growth rates of lactic acid-utilizing yeasts possibly can be expected in winter because the $\mathrm{pH}$ variations in Serra cheese are due mainly to the formation of lactic acid. Rhodotorula aurantiaca was present in both the curd and the 35-d-old cheese although at low proportions, and was more resistant and proliferating in spring than in autumn. Yarrowia lipolytica was isolated in all curds and ripened cheeses except for the curd obtained in the autumn. The proportions of Kluyveromyces marxianus (a lactose-utilizing yeast) and Pichia membranaefaciens both in the curd and the 35 - $d$-old cheese exhibited variations within the lactation season; these yeasts could be isolated in the 35-d-old cheeses made in the winter and spring but not in curds made in the autumn and spring. Trichosporum beigelii was found only in the curd, and at very low proportions (Fig. $10)$.

As final remarks, considering that Leuc. lactis, L. lactis ssp. lactis and Lact. paracasei ssp. paracasei were the most resistant and proliferating $L A B$ found in this study, further research on the possibility of including these bacteria as part of a starter and on their effects on the organoleptic characteristics of Serra cheese seems very promising. Refrigeration of ewes' raw milk on the farm level should also be optimized in order to control the growth of $H$. alvei. The temperature and relative humidity conditions of ripening must also be set and controlled because they have an influence on the growth/death rates of various microorganisms which may impart relevant organoleptic characteristics to the final Serra cheese.

\section{ACKNOWLEDGEMENTS}

The authors are grateful to Professor Edmund Zottola (University of Minnesota, USA) for critical discussions, and to the members of the technical board of ANCOSE (Associação Nacional de Criadores de Ovinos Serra da Estrela) for their cooperation encompassing the local manufacture and transport of the cheeses. Financial support for ACM was provided by a PhD fellowship (BD-1741/91-IF) granted by JNICT (Junta Nacional de Investigação Cientifica e Tecnológica) within the framework of the CIENCIA program. This R\&D work was partially funded by Agência de Inovação via project MAQUETTE (MelhorAmento de QUEijos Tradicionais e sua TEcnologia).

\section{REFERENCES}

Anon. (1993) APILAB PLUS Software. Version 3.2.2. Version B. BioMérieux, France.

Antunes, T.M. and Santos, I. (1943) Elementos para o estudo do queijo da Serra. Boletim Pecuário 11, 101-156.

Arizcun, C., Barcina, Y. and Torre, P. (1992) Identification of lactic acid bacteria isolated from Roncal cheese. In Identification of Bacteria : Present Trends-Future Prospects ed. Federation of European Microbiology Societies. pp. 58, Granada, Spain: ICE University of Granada. 
Barbosa, M., Corradini, C. and Battistotti, B. (1981) Cheesemaking experiments carried out on some Italian cheese with vegetable rennet from cardo (Cynara cardunculus, L). Scienzia Tecnica Lattiero Caserio 32, 204-221.

Barnett, J. A., Payne, R.W. and Yarrow, D. (1990) Yeasts identification PC program. Version 2.

Bautista, L., Bermejo, M.P. and Nuñez, M. (1986) Seasonal variation and characterization of Micrococcaceae present in raw ewe's milk. Journal of Dairy Sience 53, 1-5.

Collins, C.H. and Lyne, P.M. (1984) Pseudomonads, acinetobacter, alkaligenes, achromobacter, flavobacterium, chromobacterium and acetobacter. In Microbiological Methods ed. Collins, C.H. and Lyne, P.M. pp. 261-267. London: Butterworths.

Cruz, A.A. (1945) Lacticínios da Beira Baixa. Queijo à ovelheira e queijo à cabreira. Boletim Pecuário 12, 105-125.

Fernandez del Pozo, B., Gaya, P., Medina, M., Rodriguez-Marin, M.A. and Nuñez, M. (1988) Changes in the microflora of La Serena ewe's milk cheese during ripening. Journal of Dairy Research 55, 449-455.

Fontecha, J., Peláez, C., Juárez, M., Requena, T. and Gómez, C. (1990) Biochemical and microbiological characteristics of artesanal hard goat's cheese. Journal of Dairy Science 73, 1150-1157.

Gaya, P., Medina, M. and Nuñez, M. (1983) Accelerated decrease of Enterobacteriaceae counts during ripening of raw milk Manchego cheese by lactic culture inoculation. Journal of Food Protection 46, 305-309.

Gaya, P., Medina, M. and Nuñez, M. (1987) Enterobacteriaceae, coliforms, faecal coliforms and salmonellas in raw ewes' milk. Journal of Applied Bacteriology 62, 321-326.

Gomez, R., Peláez, C. and De La Torre, E. (1989) Microbiological study of semi-hard goat's milk cheese (Majorero). International Journal of Food Science and Technology 24, 147-151.

Hiscox, E.R., Rowland, S.J., Wolf, J. and Jacob, M. (1941) Nota acerca da bacteriologia e química do queijo português de leite de ovelha (Serra). Boletim Pecuário 9(4), 163-165.

Juven, B.J., Gordin, S., Rosenthal, I. and Laufer, A. (1981) Changes in refrigerated milk caused by Enterobacteriaceae. Journal of Dairy Science 64, 1781-1784.

Kandler, O. and Weiss, N. (1986) Regular nonsporing Grampositive rods. In Bergey's Manual of Systematic Bacteriology ed.
Krieg, N.R. and Holt, J.G. pp. 1209-1234. Baltimore: Williams \& Wilkins.

Kleeberger, A., Braatz, R. and Busse, M. (1980) Zur Taxonomie und Okologie der Enterobakterien in Milch. Milchwissenschaft 35, 457-460.

Macedo, A., Malcata, F.X. and Oliveira, J.C. (1993) The technology, chemistry, and microbiology of Serra cheese: a review. Journal of Dairy Science 76, 1725-1739.

Macedo, A.C., Costa, M.L. and Malcata, F.X. (1995) Characterization of the microflora of Serra cheese: Evolution throughout ripening time, lactation period, and axial location. International Dairy Journal (in press).

Nuñez, M. and Martinez-Moreno, J.L. (1976) Flora microbiana del queso Manchego I. Evolución de la flora microbiana de quesos Manchegos artesanales. Anales del Instituto Nacional de Investigaciones Agrarias 4, 33-40.

Nuñez, J.A., Chavarri, F.J. and Nuñez, M. (1984) Psychrotrophic bacterial flora of raw ewes' milk, with particular reference to Gram-negative rods. Journal of Applied Bacteriology 57, 23-29.

Nuñez, M., Medina, M. and Gaya, P. (1989) Ewes' milk cheese: technology, microbiology and chemistry. Review article. Journal of Dairy Research 56, 303-321.

Prekoppova, J. (1974) Microflora of ewe's milk Hrudkovy and Bryndza cheese. XIX International Dairy Congress. Conference proceedings, 1E, pp. 705.

Ramos, M., Barneto, J. and Ordónez, J.A. (1981) Evaluation of a specific starter for Manchego cheese production. Milchmissenschaft 36, 528-534.

Thompson, T.L. and Marth, E.H. (1986) Changes in Parmesan cheese during ripening: Microflora-coliforms, enterococci, anaerobes, propionobacteria and staphylococci. Milchwissenschaft 41, 201-204.

Tornadijo, E., Fresno, J.M., Carballo, J. and Martin-Sarmiento, R. (1993) Study of Enterobacteriaceae throughout the manufacturing and ripening of hard goats' cheese. Journal of Applied Bacteriology 75, 240-246.

Tzanetakis, N. and Litopoulou-Tzanetaki, E. (1992) Changes in numbers and kinds of lactic acid bacteria in Feta and Teleme, two greek cheeses from ewes' milk. Journal of Dairy Science 75, 1389-1393. 